\title{
The Utilization of Whatsapp Application on Scientific-Based Learning Management in Higher Education Institutions
}

\author{
I Putu Widyanto ${ }^{1}$, Achmad Slamet ${ }^{2}$, Haryono ${ }^{3}$, Titi Prihatin ${ }^{4}$ \\ ${ }^{1,2,3,4}$ Graduate School, Universitas Negeri Semarang, Indonesia \\ Corresponding email: putuwidyanto@yahoo.co.id
}

\begin{abstract}
The utilization of whatsapp application in scientific learning is able to create a conducive academic atmosphere because learners can learn everywhere and anytime. The purpose of this research is to describe the use of whatsapp application in scientific learning management, learning planning stage, learning implementation, and learning supervision by using problem-based learning method. The research used qualitative approach and descriptive design. The research was carried out at Institut Agama Hindu Negeri Tampung Penyang Palangka Raya, Indonesia. Researchers collected information through interviews. Data analysis of interview results was achieved with the interactive analysis model from Miles. The results of the research showed utilization of information and communication technology through whatsapp causes change of educators' role into facilitators in the learning process. Interactions between educators and students are no longer limited in classroom meeting but can also occur outside the classroom. Besides, students can also get information widely and quickly so that it can increase the effectiveness of the implementation of learning process that is ultimately expected to improve students learning outcomes.
\end{abstract}

Key words: scientific learning, whatsapp, learning management

\section{Introduction}

Scientific-based learning approaches are more effective than teacher centered learning (TCL). A research in TCL shows $10 \%$ retention of information from educators after fifteen minutes and $25 \%$ acquisition of contextual understanding. On the contrary, in scientificbased learning approach information retention from educators is more than $90 \%$ after two days, and the acquisition of contextual understanding is $50-70 \%$ (Budiyanto, Waluyo, \& Mokhtar, 2016). Scientific approach is a learning strategy that further empowers and encourage learners to construct their knowledge. Other than that, learners are expected to discover knowledge and skills not only by remembering a set of facts but also finding it by themselves by looking, asking, submitting hypotheses, collecting data and drawing conclusions (Katimo, Suparmi, \& Sukarmin, 2016). It can be implemented optimally, effectively and efficiently if it is supported by the management in the process of scientific learning (Mansur, 2013). Scientific learning management is an activity of a learning process management to achieve learning objectives through the interaction between learners, educators and learning resources in a learning environment (Nirwana, 2014) embracing three steps of scientific learning management which consists of planning, implementing and supervising (Terry, 2012).
The utilization of Information and Communication Technology (ICT) in Scientific learning causes change in the role of educators who are not only as a source of knowledge but also as facilitators in the learning process (Sumintono, Wibowo, Mislan, \& Tiawa, 2012). By using ICT, interactions between educators and students is no longer limited to classroom meetings but can also occur outside the classroom. In addition learners can also obtain information widely from various sources with the help of ICT (Darimi, 2017). Thus, it can improve the effectiveness of the implementation of learning process that is ultimately expected to improve students learning outcomes (Husain, 2014). One of the developing ICT applications is whatsapp, where it is not just for chatting (text messaging) and broadcast chain messaging, but rather for collaboration and information sharing that is more emphasized so that the purpose of elearning can really be achieved (Prajana, 2017). A research shows that whatsapp is able to create a conducive academic atmosphere because learners can learn everywhere and anytime where the learning implementation is presented in a relaxed learning atmosphere. Moreover, good emotional closeness is formed along with the increasing intensity of communication through social media which makes a number of new ideas related to the learning given (Kartikawati \& Pratama, 2017). However, research on the use of whatsapp application in 
scientific learning has not ever been carried out. This condition intrigues the interest of researchers in conducting a research on the use of whatsapp application in scientific-based learning management. Therefore, this research aims at describing the use of whatsapp application in scientific learning management, learning planning stage, learning implementation and learning supervision by using problem-based learning method. Moreover, this research is expected to provide an overview of the use of whatsapp applications for college lecturers.

\section{Methods}

This research used qualitative approach and descriptive design. The research was conducted at Institut Agama Hindu Negeri Tampung Penyang Palangka Raya, Indonesia. The researcher collected the data from the educators' and learners' perceptions during learning process in which they implement scientific learning management using problembased learning method supported by the whatsapp application during the learning process. Furthermore, the researchers analyzed how whatsapp application can support the implementation of scientific-based learning management. The data analysis technique used interactive interview models from Miles and Huberman.

\section{Results and Discussion}

The use of whatsapp application in learning planning stage creates a group account for discussion and preparation for learning documents in digital form so that it can be distributed to the learners during the learning process. Learning planning is an attempt to define instructional procedures and systemized learning process in certain situations so that the expected changes in behaviorin the students themselves could occur (Asmadawat, 2014). In learning planning, the educators carry out the preparation process of the learning tools, the use of ICT, the use of approaches and methods of learning and assessment (Nadzir, 2013). In addition, the educators also formulate lesson plan program (Setyawan, S., \& Basuki, 2012) and submit the lesson plan and learning tools to be evaluated by the study program (Sagala, 2011). Using whatsapp group can greatly enhance the educators' and learners' experience that can be brought together virtually, in which they can directly communicate and conduct learning activities. Besides, the educators can share writing, voicemail features, and video messages (Tikno, 2017).

The use of whatsapp application in learning implementation lies in the stage of collecting information and processing information. In the stage of collecting information, the educators are able to provide input in the discussion forum on whatsapp application during the process of collecting data conducted by the students, and the students are also able to ask for input from the educators about the obtained data. While in the stage of processing information, the educators will provide special time as facilitators to put the students in one group through a discussion forum in the whatsapp application to process various data obtained which can be concluded and presented later. Activities undertaken by the educators through whatsapp application is a function of educators as facilitators outside the classroom in preparing tools or procedures to encourage and actively involve all students in the group to study, and this is known as participatory approach (Nainggolan, Mariah, \& Kurniawan, 2017).

Learning implementation is a real application of the lesson plan that was made by educators (Novalita, 2014) in which it is one of the external factors affecting learning outcomes. If learning implementation is considered good, the learning objectives will be well achieved (N. G. A. A. L. Dewi, Tripalupi, \& Artana, 2013). The implementation of problem-based learning involves three stages. The first stage consists of observing stages, where the students are given problems that contain phenomena that require explanation (Wicaksana \& Usodo, 2016) and questioning stage in the form of activities undertaken by the students to make inquiries from information that is not understood. Therefore, making students think critically of the things observed develops creativity and curiosity (Santi, 2017). Then, the second stage which is held outside the classroom embraces collecting information from sources such as literature, questionnaires, interviews, and researches to obtain the answers of the existing questions (Deden, 2015) and processing information, which is in the form of meaningful process involving the use of knowledge from several sources that must be studied to increase the breadth and depth of the information studied (P. S. Dewi \& Diana, 2015). Finally, the third stage which is re-implemented in the classroom 
is communicating stage, which is in the form of presentation of the students' observations results and conclusions in front of the class based on the results of oral and written analysis. In this case, the students work in groups and can provide comment on the given presentations (Rusman, 2017).

The use of whatsapp application in learning supervision stage comprises monitoring, supervision, reporting and followup. In monitoring stage, the educators can monitor the discussion activity in whatsapp group in which the monitoring process can see whether the discussion goes as expected. In supervision stage, the educators can provide initial assistance and guidance both individually and collectively when the students have difficulties during learning process or when it is necessary to hold face-to-face sessions for further process. In reporting stage, the educators can provide progress of the students' learning outcomes so that information of learning development can be realized through whatsapp application. In follow-up stage, the educators can provide information on remedial activities, enrichment, counseling, and/or assignment for the students directly so that they can receive the information quickly. Supervision by the educators through whatsapp application is carried out in order to find out whether what is implemented corresponds to what is planned. Once problems are found, the shortcomings should be identified, and solutions are needed quickly and comprehensively to overcome the problems (Kuat, 2015).

Learning supervision is an activity to match whether learning process corresponds to the plans in achieving learning objectives (Kuat, 2015), by observing systematically and continuously, recording, giving explanations and guidance, coaching, correcting less appropriate things and fixing errors (Mansur, 2013). Supervision of the learning process is conducted through monitoring, supervision, evaluation, reporting, as well as providing follow-up on a regular basis and continuously (Puspitasari, 2017). Monitoring activity is a process of collecting and analyzing information based on the indicators so that corrective actions can be given to refine the next learning process (Widiastuti \& Susanto, 2014). Learning supervision activities are efforts to provide service and assistance for students both individually and collectively as an effort to improve learning process so that learning situation becomes more effective and efficient (S, Usman, \& Niswanto, 2017) conducted in planning, implementation, and assessment of learning outcomes through sampling, discussion, consultation or training (Puspitasari, 2017). Program Evaluation is an activity to determine the level of success or achievement of objectives of a program based on planning to determine follow-up of programs that are or have been implemented (Mahmudi, 2011). Report of the learning outcomes is a record of the results of learning monitoring and evaluation in the form of qualitative or quantitative design using the instruments (Triwiyanto, 2015). The report must be done objectively, accountably, and informatively (Ediawati, Sudiana, \& Wisudariani, 2016). Follow-up in learning activities is an activity undertaken by educators after submitting the evaluation reports (Agensyah, Darwanis, \& Syahputra., 2017). The follow-up is based on the evaluation data that has been compiled, organized, processed, analyzed and concluded so that the meaning contained can be known. Thus, the evaluation eventually can be used to make decisions or formulate policies that will be considered necessary as a follow-up for evaluation activities (Riadi, 2017), whether it is in the form of remedies, enrichment, counseling, and/or tasks(Lukum, 2015).

\section{Conclusion}

Based on the research results, it can be drawn some conclusions that the utilization of whatsapp application in science-based learning management with problem-based learning methods includes several stages. In learning planning stage, a group discussion account is created, and learning documents in digital form are prepared. In learning implementation stage, the educators can provide input in the discussion forum and give a special time as facilitators to gather the students into one group through discussion forums in the whatsapp application to process various data that needs to be concluded and presented later. In learning supervision stage, the educators can monitor discussion activities in the whatsapp group. The educators can provide assistance and early guidance both individually and collectively if the students have difficulties during the learning process. Educators can also provide information showing students' progress on learning outcomes. Moreover, they can share information about remedy, enrichment, counseling, and/or 
assignment for students through whatsapp. The utilization of whatsapp applications in scientific learning provides benefits among others. It changes the educators' role into facilitators in learning process. Interactions between the educators and students are no longer limited in classroom meeting but can also occur outside the classroom. Besides, the students can also get information widely and quickly so that it increase the effectiveness of the implementation of the learning process that is ultimately expected to improve students learning outcomes.

\section{References}

Agensyah, A., Darwanis, \& Syahputra., M. (2017). Pengaruh Efektivitas Pengawasan, Frekuensi Pemeriksaan Dan Tindak Lanjut Temuan Inspektorat Terhadap Kinerja Satuan Kerja Pemerintah Aceh Pada Provinsi Aceh. Jurnal Akuntasi Pascasarjana Universitas Syiah Kuala, 6(1), 1-10.

Asmadawat. (2014). Perencanaan Pengajaran. Jurnal Darul 'Ilmi, 2(1), 1-13.

Budiyanto, M. A. K., Waluyo, L., \& Mokhtar, A. (2016). Implementasi Pendekatan Saintifik dalam Pembelajaran di Pendidikan Dasar di Malang. Proceeding Biology Education Conference, 13, 46-51. Surakarta: FKIP UNS.

Darimi, I. (2017). Teknologi Informasi dan Komunikasi Sebagai Media Pembelajaran Pendidikan Agama Islam Efektif. Cyberspace, Jurnal Pendidikan Teknologi Informasi, 1(2), 111-121.

Deden. (2015). Penerapan Pendekatan Saintifik Dengan Menggunakan Model Pembelajaran Inkuiri Pada Mata Pelajaran Ekonomi. Prosiding Seminar Nasional 9 Mei 2015, 98-107.

Dewi, N. G. A. A. L., Tripalupi, L. E., \& Artana, M. (2013). Pengaruh pelaksanaan pembelajaran dan kebiasaan belajar terhadap hasil belajar ekonomi kelas x sma lab singaraja 1. Jurnal Jurusan Pendidikan Ekonomi, 3(1).

Dewi, P. S., \& Diana, R. (2015). Implementasi Pendekatan Saintifik Terhadap Proses Aktivitas Guru dan Siswa pada Pembelajaran IPA Terpadu. Prosiding Simposium Nasional Inovasi dan Pembelajaran Sains 2015 (SNIPS 2015), 2015, 489-492. Bandung.

Ediawati, A., Sudiana, I. N., \& Wisudariani, N.
M. R. (2016). Penilaian Autentik Dalam Pembelajaran Menulis Teks Ulasan Di Kelas VIII a9 Smp Negeri 1 Singaraja. EJournal Pendidikan Bahasa Dan Sastra Indonesia Universitas Pendidikan Ganesha, 5(3).

Husain, C. (2014). Pemanfaatan Teknologi Informasi dan Komunikasi dalam Pembelajaran di SMA Muhammadiyah Tarakan. Jurnal Kebijakan Dan Pengembangan Pendidikan, 2(2), 184-192.

Kartikawati, S., \& Pratama, H. (2017). Pengaruh Penggunaan WhatsApp Messenger Sebagai Mobile Learning Terintegrasi Metode Group Investigation Terhadap Kemampuan Berpikir Kritis. Jupiter: Jurnal Pendidikan Teknik Elektro, 2(2), 33-38.

Katimo, Suparmi, \& Sukarmin. (2016). Pengaruh pembelajaran dengan pendekatan saintifik menggunakan metode eksperimen dan demonstrasi terhadap prestasi belajar dan kreativitas ditinjau dari sikap ilmiah. Jurnal Inkuiri, 5(2), 87-93.

Kuat, T. (2015). Penumbuhan Jiwa Kewirausahaan Melalui Praktik Bisnis Di Business Center ( Studi Kasus: SMK Muhammadiyah 2 Surakarta). Jurnal Pendidikan Ilmu Sosial, 25(1), 155-168.

Lukum, A. (2015). Evaluasi Program Pembelajaran IPA SMP Menggunakan Model Countenance Stake. Jurnal Penelitian Dan Evaluasi Pendidikan, 19(1), 25-37.

Mahmudi, I. (2011). CIPP: Suatu Model Evaluasi Program Pendidikan. Jurnal AtTa'dib, 6(1), 112-124.

Mansur, N. (2013). Meningkatan Mutu Pendidikan Melalui Penerapan Manajemen Berbasis Sekolah. Jurnal Ilmial Didaktika, XIV(1), 24-42.

Nadzir, M. (2013). Perencanaan Pembelajaran Berbasis Karakter. Jurnal Pendidikan Agama Islam, 2(2), 339-352.

Nainggolan, E., Mariah, S., \& Kurniawan, F. (2017). Internalisasi Asumsi Pembelajaran Andragogi Pada Mata Kuliah Statistik. Jurnal Keluarga Sehat Sejahtera, 15(29), $1-14$.

Nirwana. (2014). Pengaruh Manajemen Lingkungan Dan Gaya Kognitif Terhadap Hasil Belajar IPA-Fisika Di SMPN Kota Bengkulu ( Studi eksperimen pada siswa kelas VII Semester I SMPN 11 Kota Bengkulu) 2012. In Prosiding Seminar Nasional Fisika (E-Journal) SNF2014, 71- 
79.

Novalita, R. (2014). Pengaruh Perencanaan Pembelajaran Terhadap Pelaksanaan Pembelajaran (Suatu Penelitian terhadap Mahasiswa PPLK Program Studi Pendidikan Geografi FKIP Universitas Almuslim). Lentera, 14(2), 56-61.

Prajana, A. (2017). Pemanfaatan Aplikasi Whatsapp Dalam Media Pembelajaran Di Uin Ar-Raniry Banda Aceh. Cyberspace: Jurnal Pendidikan Teknologi Informasi, l(2), 122-133.

Puspitasari, H. (2017). Standar Proses Pembelajaran Sebagai Sistem Penjaminan Mutu Internal Di Sekolah. Muslim Heritage, 1(2), 339-368.

Riadi, A. (2017). Problematika sistem evaluasi pembelajaran. Ittihad Jurnal Kopertais Wilayah XI Kalimantan, 15(27), 1-12.

Rusman. (2017). Belajar \& Pembelajaran Berorientasi Standar Proses Pendidikan. Jakarta: Kencana.

S, M., Usman, N., \& Niswanto. (2017). Evektifitas Pelaksanaan Tugas Pengawas dalam Meningkatkan Mutu Pendidikan pada Sekolah Dasar Lingkungan UPTD Suku I Disdikpora Kota Banda Aceh. In Prosiding Seminar Nasional Pascasarjana Unsyiah, 154-159. Banda Aceh: Unsyiah.

Sagala, S. (2011). Manajemen Strategik Dalam Peningkatan Mutu Pendidikan. Bandung: Alfabeta.

Santi, O. S. (2017). Perbedaan Prestasi Belajar Siswa Melalui Pendekatan Saintifik Dan Pendekata Keterampilan Proses Pada Mata
Pelajaran IPA. Jurnal Bidang Pendidikan Dasar (JBPD), 1(1), 81-88.

Setyawan, A., S., S. H., \& Basuki, I. A. (2012). Rencana Pelaksanaan Pembelajaran Guru Bahasa Indonesia Tingkat SMP di Kota Malang. Jurnal Online UM, 1(1), 1-5.

Sumintono, B., Wibowo, S., Mislan, N., \& Tiawa, D. (2012). Jurnal Pengajaran MIPA, Volume 17, No 1, April 20121. Jurnal Pengajaran MIPA, 17(1), 122-131.

Terry, G. R. (2012). Asas - Asas Manajemen Edisi Kedelapan. Terjemahan Winardi. Bandung: PT Alumni.

Tikno. (2017). Analisis Penerimaan Grup WhatsApp Sebagai Sarana Komunikasi dan Pembelajaran dari Perspektif Mahasiswa. Jurnal Sistem Informasi Indonesia, 2(1), 1-13.

Triwiyanto, T. (2015). Pelaksanaan Monitoring, Evaluasi, Dan Pelaporan Untuk Penilaian Kinerja Manajerial Kepala Sekolah. Cakrawala Pendidikan, XXXIV(1), 67-77.

Wicaksana, H., \& Usodo, B. (2016). Eksperimentasi Model Pembelajaran Problem Based Learning Dan Discovery Learning Dengan Pendekatan Saintifik Pada Materi Himpunan Ditinjau Dari Adversity Quotient Siswa. Jurnal Elektronik Pembelajaran Matematika, 4(3).

Widiastuti, N. I., \& Susanto, R. (2014). Kajian Sistem Monitoring Dokumen Akreditasi Teknik Informatika Unikom. Majalah Ilmiah Unikom, 12(2), 195-202. 